\title{
Review of research on thermal problems in TUG
}

by $A$. Nowakowski*

\author{
* Gdansk Univ. of Technology, 11/12 Narutowicza Str., 80-233 Gdansk, Poland, antowak@pg.gda.pl
}

\section{Abstract}

This is a prospective review of 50 years of research on thermal problems in Gdansk University of Technology, Faculty of Electronics (TUG). Main focus of this research was on metrology of thermal processes mainly using IR technology but also on development of instrumentation, analysis of thermal phenomena in semiconductor devices and applications to non-destructive testing in industrial processes as well as novel applications in medical diagnostics. Here the projects performed by the research team lead by the author of this text are presented.

The main focus of research shifted in time due to general changes of economy and political situation in Poland. The early work was influenced by many constrictions - limited scientific exchange under "the iron curtain" countries as was Poland, very poor money exchange rate leading to interests on solving solutions already available in so called "the free world" but too expensive to be imported, export-import political restrictions etc.

The early interests of the thermal research team came from industry and science suffering lack of availability of modern measurement instrumentation. This was especially painful in infrared domain strictly controlled by embargo restrictions. As the result several unique pyrometric type instruments were developed. An IR thermometer to measure temperature of electric motor internal rotating elements; a scanning radiation pyrometer for analysis of temperature distribution in thick film electronic devices, both using non-selective thermistor bolometer detectors. Then, a twowavelength pyrometer for measurements and control of temperature of cement mills scorch zone supplied by coal powder, operating in near IR. Following was a mirror scanning microscope with MCT cooled detector to study temperature distribution in semiconductor structures; finally series of TGS long wavelength IR detectors applied to handheld pyrometers to detect fires in coal mines. All those instruments were developed within the period $1967-1973$ and allowed to prepare a PhD dissertation [1], devoted to analysis of detection limits in optical pyrometry.

The following period 1975 - 1990 was important for advanced studies on thermal problems in semiconductor devices. Three members of the thermal problems research team completed DSc - habilitation dissertations [2, 3, 4]. As practical implementation of the research results several advanced measurement and testing sets have been developed and implemented for industrial production control in the CEMI, Centre of Semiconductors and the factory TEWA. Most advanced were: a microscope to study recombination radiation of high power diodes and thyristors, operating in near IR; testers for non-destructive determination of second breakdown of high power transistors; several automatic sets of SOA - safe operation area of different semiconductor devices; several instruments for determination of thermal resistance and thermal impedance of diodes, transistors and integrated circuits.

After political changes in 90-ties XX Century in Poland electronic industry collapsed and our research shifted to medical applications, especially to development of active thermography and new diagnostic methods in skin burn treatment, cardiosurgery and other applications. The scientific results were summarised in several PhD dissertations, as e.g. $[5,6,7,8]$. The main reason of following fast development of research infrastructure was availability of modern IR cameras, what allowed Poles to join to the advanced European Research Area. So, the author came back to his original research interests, defined in his MSc project [9], called a medical thermograph. In fact this was a trigger allowing to accelerate development of modern research resulting in publication of several books $[10,11,12,13,14,15,16,17]$ and many original scientific articles, not cited here.

Important factor of fast development of medical applications was organisation of a new department of Biomedical Engineering at the Faculty of Electronics in 1991. This triggered also fast development of common research with several departments and clinics of Gdansk Medical University, especially in oncology, plastic surgery, cardiology and cardiosurgery and other as well as with the Department of Animal Physiology Gdansk University. The main important results of this work were developments of new diagnostic methods, as objective quantitative determination of depth of skin burns, evaluation of cardiosurgery procedures, including study of post-surgery healing processes and many other. This resulted by several dissertations in medicine - dr Siebert PhD and then DSc in cardiology, dr Renkielska DSc in plastic surgery and several other PhD dissertations and in physiology - dr Stojek - DSc. Our common publications are broadly cited. The last ones, some-how summaries of recent research were published in 2016 [18, 19]. In parallel strong educational activity in Biomedical Engineering resulted in formal recognition of the Department as one of leading institutions in Poland in this field. Since 2008 we are running interfaculty study of Biomedical Engineering at the BSc and MSc levels, in 2013 we have got the right to run $\mathrm{PhD}$ study in the Biocybernetics and Biomedical Engineering discipline and finally in 2016 we received the authorization for granting DSc (habilitation) in this discipline. 


\section{REFERENCES}

[1] Nowakowski A.: Analiza ekstremalnych właściwości detekcyjnych pirometrów - Analysis of detection limits in pyrometry, PhD dissertation, Politechnika Gdańska, 1973.

[2] Stepowicz W., DSc dissertation, Nieizotermiczne charakterystyki prądowo-napięciowe wybranych elementów półprzewodnikowych, ZNPG nr 376, Elektronika 56, 1984.

[3] Janke W., DSc dissertation, Modele elektrotermiczne elementów półprzewodnikowych, ZNPG nr 374, Elektronika 57, Gdańsk, 1984.

[4] Nowakowski A., DSc dissertation, Badanie procesów termicznych w przyrządach półprzewodnikowych. Zesz. Nauk. P.Gdań. nr 389, Elektronika, nr 60, 1985.

[5] Gajkiewicz J., Pomiarowe i symulacyjne metody badania wybranych problemów termicznych w tranzystorach bipolarnych, PhD dissertation, Politechnika Gdanska, 1990.

[6] Kaczmarek M., Modelowanie właściwości termicznych tkanek żywych dla potrzeb termografii dynamicznej, PhD dissertation, Politechnika Gdańska, 2003,

[7] Hryciuk M., Analiza właściwości termicznych tkanek biologicznych, PhD dissertation, Politechnika Gdanska, 2003.

[8] Moderhak M., Analiza algorytmów diagnostyki termicznej dla mammografii, PhD dissertation, 2013.

[9] Nowakowski A., Termograf medyczny, MSc diploma project, Politechnika Warszawska, 1967.

[10] Nowakowski A., Quantitative Active Dynamic Thermal IR-Imaging and Thermal Tomography in Medical Diagnostics, 7-1 - 7-30, and Nowakowski A., Kaczmarek M., Rogowski J., The Role of Thermal Monitoring in Cardiosurgery Interventions, 17-1 - 17-24, in ed. M. Diakides, J.D. Bronzino, D.R Petereson, Medical Infrared Imaging - Principles and Practices, CRC Press, Taylor \& FrancisGroup, Boca Raton, 2013.

[11] Nowakowski A., red., Rozwój diagnostyki termicznej metodami detekcji podczerwieni (ilościowa diagnostyka ran oparzeniowych i inne aplikacje), AOW EXIT. Warszawa, 2009.

[12] Nowakowski A., red., Analiza technik diagnostycznych i terapeutycznych w celu oceny procedur kardiochirurgicznych, AOW EXIT, Warszawa, 2008.

[13] Nowakowski A., red. Diagnostyka termiczna w podczerwieni do oceny gojenia ran pooperacyjnych, AOW EXIT, Warszawa 2016

[14] Nowakowski A., red. Proc. the $133^{\text {rd }}$ ICB Seminar on "Advances of InfraRed thermal imaging in medicine" 30 June - 3 July 2013, Wyd. IBIB PAN, Warszawa, 2013

[15] Nowakowski A., Kaczmarek M., Siebert J., Rogowski J., Zastosowanie termografii w nadzorze interwencji kardiochirurgicznych, 549-560, and Nowakowski A., Kaczmarek M., Hryciuk M., Tomografia termiczna, 615696, Biocybernetyka i Inżynieria Biomedyczna 2000, Tom 8: Obrazowanie medyczne; [red.] L. Chmielewski, J. L. Kulikowski, A. Nowakowski, AOW EXIT, Warszawa 2003.

[16] Nowakowski A., Kaczmarek M., Renkielska A., Aktywna Termografia Dynamiczna, 193 - 214, w red. Podbielska H., Skrzek A., Biomedyczne zastosowania termowizji, Oficyna Wyd. Politechniki Wrocławskiej, Wrocław 2014.

[17] Kaczmarek M., Nowakowski A., Monitorowanie Zabiegów Kardiochirurgicznych, 215 - 242, w red. Podbielska H., Skrzek A., Biomedyczne zastosowania termowizji, Oficyna Wyd. Politechniki Wrocławskiej, Wrocław 2014

[18] Nowakowski A., Siondalski P. , Moderhak M. and Kaczmarek M., A new diagnostic method for evaluation of cardiosurgery wound healing, Quantitative InfraRed Thermography Journal, DOI: 10.1080/1766733.2015.1077534, 1 - 16, 2015.

[19] M Kaczmarek, A Nowakowski, Active IR-Thermal Imaging in Medicine, Journal of Nondestructive Evaluation 35 (1), 1-16, 2016. 